Journal of Advanced Research in Fluid Mechanics and Thermal Sciences

\title{
Numerical Analysis of Phenomena Transport of a Proton Exchange Membrane (PEM) Fuel Cell
}

\author{
Yusuf Dewantoro Herlambang ${ }^{1}$, Fatahul Arifin ${ }^{2,}{ }^{*}$, Kurnianingsih $^{3}$, Totok Prasetyo $^{1}$, Anis Roihatin ${ }^{1}$ \\ Department of Mechanical Engineering, Politeknik Negeri Semarang, Semarang 50275, Indonesia \\ Department of Mechanical Engineering, Politeknik Negeri Sriwijaya, Palembang 30139, Indonesia \\ Department of Electrical Engineering, Politeknik Negeri Semarang, Semarang 50275, Indonesia
}

\section{$\begin{array}{ll}\text { ARTICLE INFO } & \text { ABSTRACT }\end{array}$}

Article history:

Received 9 October 2020

Received in revised form 17 February 2021

Accepted 22 February 2021

Available online 3 March 2021

\section{Keywords:}

PEM fuel cell; low temperature; current distribution; numerical simulation

\begin{abstract}
The investigation the PEM fuel cell under various conditions was carried out through numerical simulation. The results revealed that the mass transport resistance, the ionic resistance, and charge transfer resistance defined the current distribution in the cathode catalyst layer. The highest current distribution in the cell was determined by the highest depletion of oxygen concentration in the exit side of the channel, and the amount of the reacted and carried oxygen towards the electrode surface of the mass transfer conditions. Among all simulation conditions, the current density on the shape gas channel with the channel ratio height-width $1: 1$ and $2: 1$ was 1,061 and $1,078 \mathrm{~A} / \mathrm{m}^{2}$, respectively, with the power density of the cell was $3,714 \mathrm{~W} / \mathrm{m}^{2}$ and $3,776 \mathrm{~W} / \mathrm{m}^{2}$, respectively.
\end{abstract}

\section{Introduction}

Proton exchange membrane (PEM) fuel cell, sometimes also known as proton electrolyte membrane fuel cell which performs as the separator to prevent the reactants (in this study were $\mathrm{H} 2$ and 02) from mixing in the cell channel, then carried protons from the anode side to the cathode side [1-3]. A carbon-supported platinum or platinum alloy nanocatalyst as well as Nafion binderwhich is an electrolyte that extending the electrochemical three-phase boundary formation, composed the catalyst later. The main composition of gas diffusion layer (GDL) is PTFEhydrophobized carbon paper or carbon cloth. The reactant transports through GDL to CL where the $\mathrm{H} 2 \mathrm{O}$ product flows out at the cathode side $[4,5]$. Bipolar plate (BPP) composed of gas-impermeable carbon plate or protective layer coated metal plate. BPP plays a role as the current collector. The flow field is available between the BPP and DL; it consists of gas channels grooved on the surface of BPP [6-8].

A phenomenon of hydrogen electrochemical oxidation was occurred in the anode during the run of PEMFC. The formed $\mathrm{H}^{+}$transports through the PEM; followed by electrochemical reduction of

\footnotetext{
* Corresponding author.

E-mail address: farifinus@polsri.ac.id

https://doi.org/10.37934/arfmts.80.2.127135
} 
oxygen at the cathode. The combination of oxygen in the cathode and protons in the anode forms $\mathrm{H}_{2} \mathrm{O}$. There is electron transportation through the external that formed a close circuit and generated the electric power $[9,10]$. Water was produced due to electrochemical reactions on the side of the cathode [11]. In addition to this, water products will be produced if the hydrogen fuel is derived from reforming hydrocarbon fuels such as natural gas, alcohol, or diesel. The build-up of water in the cells results in a lower partial pressure of hydrogen and oxygen in the anode and the cathode; this will result in a decreased cell rate in the electrochemical reaction [12-14].

The concentration of water on the side of the cathode in the cell will make a favourable impact on the ion/proton conductivity of membranes, but if the water is condensed in a cell can result in Phosphoric acid leaching out of the polymer matrix, irreversible reducing ions (protons) Perform membrane capability and entire cell performance. Operating the system at normal condition of above $100^{\circ} \mathrm{C}$, water usually does not turn into a condensate inside the cell, but the knowledge of the water content in the electrode porous during cell operation is also desirable to optimize the shutdown procedure.

Due to water condensation at the temperature of $<100^{\circ} \mathrm{C}[15,16]$. In addition to investigating the influence of steady transport of the reactants and water in cells including an anode and cathode mass and the momentum of transportation phenomenon in the flow channel, including there is a diffusion of gas (GDLs) and porous electrodes, as well as electrochemical currents in GDLs, porous and polymer electrodes membrane, will also be simulated and discussed in this study.

\section{Methodology}

The numerical simulation performed in this study with the computation domain shown in Figure 1 was carried out by commercially available software, COMSOL 5.1. The following assumptions and boundary conditions was applied in the execution of 3-dimensional numerical simulation $[17,18]$.

i. Fuel cell system is a three-dimensional, isothermal domain, steady-state, and laminar flow

ii. Electrodes are considered as anisotropic and homogeneous porous media

iii. The electrochemical reactions are considered to be gaseous phase reactions and considered to be no crossover of gases

iv. The Brinkman equation is used to describe the porous media flow in the GDL

v. Butler-Volmer kinetics defines the electrochemical reaction that occurs at $300 \mathrm{~K}$ and $1 \mathrm{~atm}$ to obtain the $\mathrm{V}-\mathrm{I}$ and $\mathrm{P}-\mathrm{I}$ curves

The schematic explains the computation domain and geometry of the PEM fuel cell, as given in Figure 1. The PEM fuel cell with a 20-mm-long, 1-mm-wide, and 1-mm-high cell channel were numerically investigated at volumetric flow rates of $0.5 \mathrm{~mL} / \mathrm{min}$.

The single cell of PEM fuel cell shown in Figure 1(a) was centrally located in the computation domain in Figure 1(b). The set of partial differential equations expressing the mass conservation, momentum and species transport in the computational domain in three-dimensional Cartesian coordinates are listed as Eq. (1), Eq. (2) and Eq. (3), respectively [19-21]. 


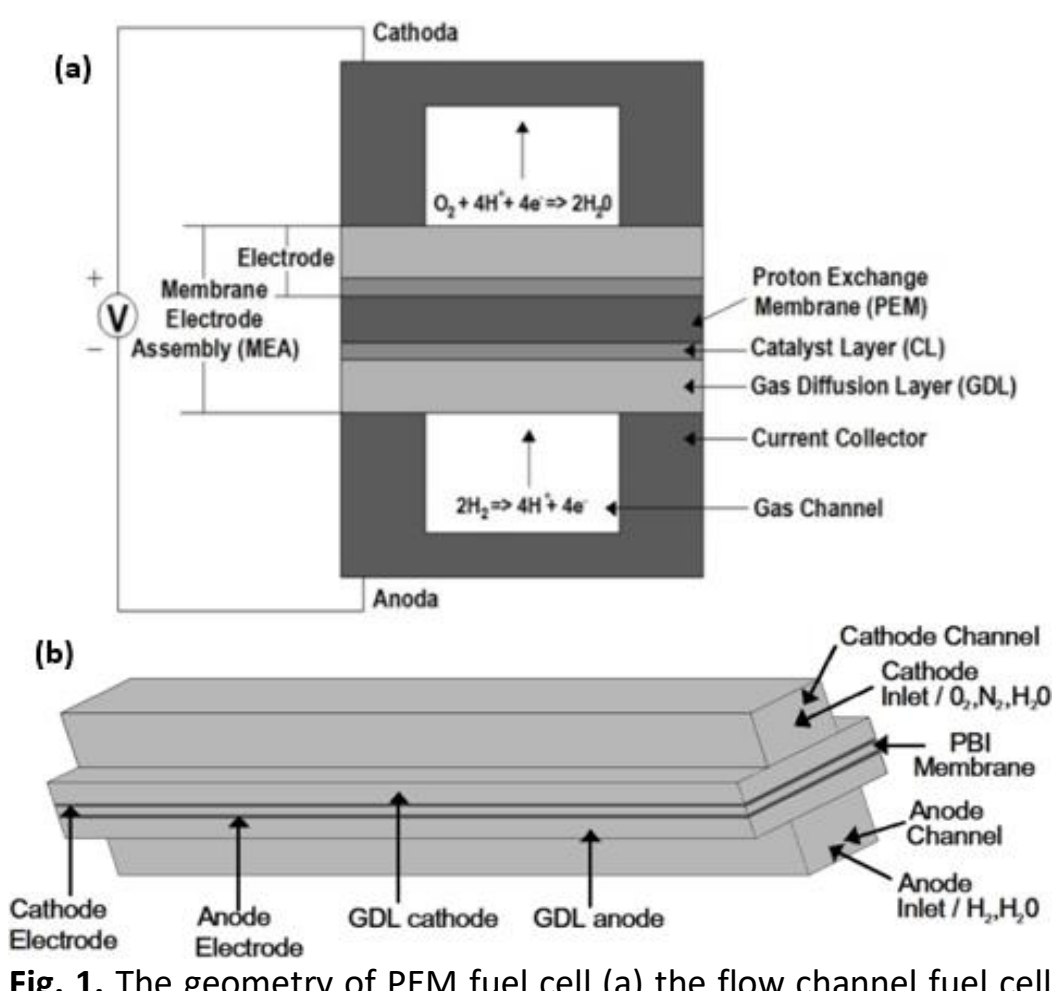

Fig. 1. The geometry of PEM fuel cell (a) the flow channel fuel cell and boundaries of the computational domain; (b) 3-D computational model a single cell of PEM fuel cell

$\rho(\nabla \cdot \vec{u})=0$

$\rho(\vec{u} \cdot \nabla \vec{u})=-\nabla p+\mu\left(\nabla^{2} \vec{u}+\left(\nabla^{2} \vec{u}\right)^{T}\right)$

$\nabla \cdot(-D \nabla c+c \vec{u})=0$

$\sigma \nabla \cdot \nabla \phi=0$

where $\vec{u}, \rho, \mu, p, c, D, \sigma_{s}, \phi_{s}$ are the velocity vector, the fluid density, fluid viscosity, static pressure, the local concentration of the species in the anode and cathode, the diffusion coefficient of species, the electronic/electrolyte conductivity, and the over potential in catalyst layer/electrolyte. Brinkman equation covers the porosity in the permeability of porous medium that are applied to define the consumption of the species. The stages of development of PEM fuel cells can be explained in the algorithm flow chart of power-density voltage-flow shown in Figure 2 . This stage describes the performance of fuel cells ranging from simulated analysis related to the concentration of hydrogen, oxygen, and water gases resulting from the electrochemical reaction process in the cell $[22,23]$. The analysis of current density resulting from the electrode surface. 


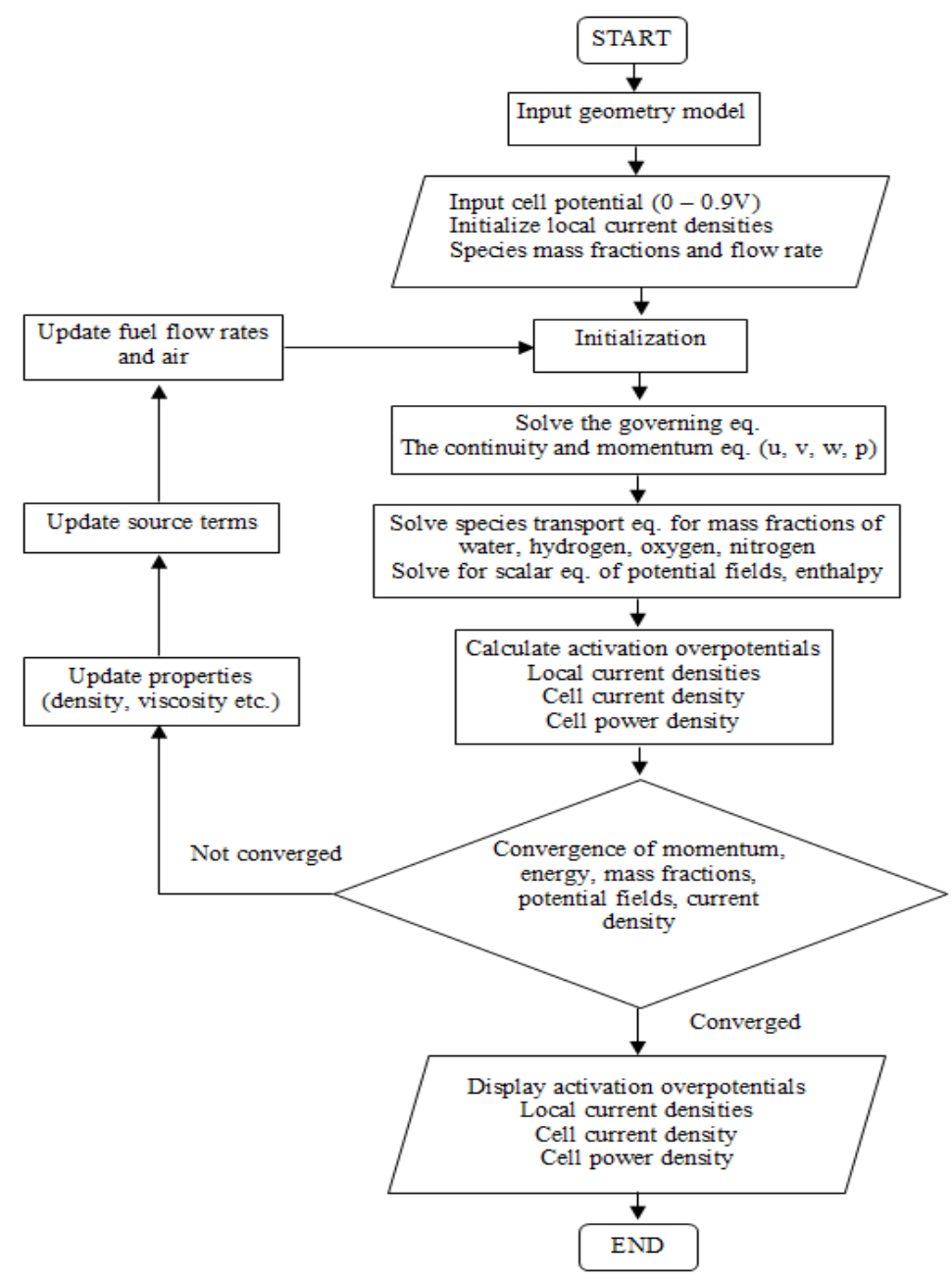

Fig. 2. The voltage-current-power density (VCP) algorithm

\section{Results}

The electrochemical currents is modelled by applying the Secondary Current Distribution interface using Ohms law and solving for $\phi_{s}$ in the GDLs, $\phi_{s}$ and $\phi_{l}$ in the porous electrodes, and $\phi_{l}$ the electrolyte membrane. In the porous electrodes, not only the ionic and electronic potentials define the local current densities, but also local reactant concentrations [24-26]. The oxidation of hydrogen happened on the anode as given by the following equation

$$
H_{2} \Rightarrow 2 H^{+}+2 e^{-}
$$

It is assumed that there is no involvement of water molecules in the transport of proton, and the below local current density equation is applied for the reaction of hydrogen oxidation

$$
i_{a}=i_{0, a}\left(\frac{c_{H_{2}}}{c_{H_{2}, r e f}}\right)^{0.5}\left(\frac{\alpha_{a, a}+\alpha_{c, a}}{R T} F \eta_{a}\right)
$$


where $c_{\mathrm{H}_{2}}$ is the local hydrogen concentration and $c_{\mathrm{H}_{2}, \text { ref }}$ is a hydrogen reference concentration (this is a linearized concentration-dependent Butler-Volmer expression). Water formation is taken place at the cathode as a result of oxygen and protons reactions, as given by the following equation

$\mathrm{O}_{2}+4 \mathrm{H}^{+}+4 e^{-} \Rightarrow 2 \mathrm{H}_{2} \mathrm{O}$

The reaction of oxygen reduction is happened by following current density equation

$i_{c}=-i_{0, a}\left(\frac{c_{O_{2}}}{c_{O_{2, \text { ref }}}}\right) \exp \left(-\frac{\alpha_{c, c}}{R T} F \eta_{c}\right)$

where the $c_{\mathrm{O}_{2}}$ is the local hydrogen concentration and the $c_{O_{2, n f}}$ is oxygen reference concentration. (This simplified concentration-dependent Butler-Volmer equation omitted the anodic term, it is known as a concentration-dependent Tafel-equation). The boundaries of anode GDL facing the flow pattern ribs are put to electronic potential of zero and the corresponding boundaries at the cathode side are put to the cell potential. The other external boundaries are electrically isolated. Mass transfer consists of parameters $w_{\mathrm{H}_{2}}, w_{\mathrm{H}_{2} \mathrm{Oa}}, w_{\mathrm{O}_{2}}, w_{\mathrm{H}_{2} \mathrm{Oa}}, w_{\mathrm{H}_{2} \mathrm{Oc}}$, and $w_{\mathrm{H}_{2} \mathrm{Oa}}$ are solved for in the flow channels, GDLs and porous electrode using in the Maxwell-Stefan equations in two different Reacting Flow in Porous Media, Concentrated Species interfaces.

Each electrode compartment occupies an interface; while hydrogen and water species are available on the anode. At the interface of secondary current distribution, a coupling is made that serves as a mass source and a sink. The mass fraction is determined at the inlet, while the outflow conditions are applied at the outlet channels. The zero flux condition is applied to all other external boundaries conditions.

The Navier-Stokes equations are used to model the momentum transfer of $u$ and $p$ in the flow channels while the Brinkman equations are applied to that of in the porous gas diffusion layers (GDLs) and electrodes using the Reacting Flow in Porous Media, Concentrated Species interface [27-29]. At the interface of Secondary Current Distribution, a coupling is built to define the mass and sink sources at the porous electrode. The velocity profiles of laminar inlet flow is determined at the boundaries of flow channel inlet, while pressure is defined at the boundaries of flow channel outlet. A multiple parallel channel configuration is modelled by applying symmetry boundary conditions along the long sides of the GDLs and the porous electrodes. No slip conditions are applied for all other wall boundaries.

Figure 3 describes the ionic current in the z-direction at the centre of the membrane for $0.4 \mathrm{~V}$. It is revealed that in the $y$-direction there is a phenomenon of lower current density than that of the outlet. It could be caused by the lower reactant concentrations. The $x$-direction shows that at the closest region to the channel, the highest currents density is found. The current density decreases towards the centre of the channel along with the decrease of reactant concentrations. This is due to Ohmic drops in the GDLs. The performance of fuel cells under the ratio variation of height to width of cell channel at hydrogen concentration of $0.05-\mathrm{M}$ and volumetric flow rates of $0.5 \mathrm{~mL} / \mathrm{min}$ is described in Figure 3. Along with the increase of flow rate or concentration, the performance of the fuel cell increases in the sequence of model-1, model-2, model-3, and model-4, respectively. Similar to the performance of cell at $0.05-\mathrm{M} \mathrm{H} 2$ with a volumetric flow rate of $0.5 \mathrm{~mL} /$ minute, the cell current densities at the anode electrode were $0.106,0.108,0.095$, and $0.096 \mathrm{~A} / \mathrm{m}^{2}$, respectively. The fuel concentration will only increase at the membrane conductivity of $9.825 \mathrm{~S} / \mathrm{m}$. This phenomenon 
exhibits the increase of fuel transports towards the anode electrode by the increase of volumetric flow rate. The effects gradually decrease that the concentration loss due to the inadequate amount of oxygen transport from the ambient air towards the gas difussion layer to the cathode electrode occurs later. Commonly, the volumetric flow rate as well as the higher concentration tend to enhance cell performance, including cell current density and cell power density.

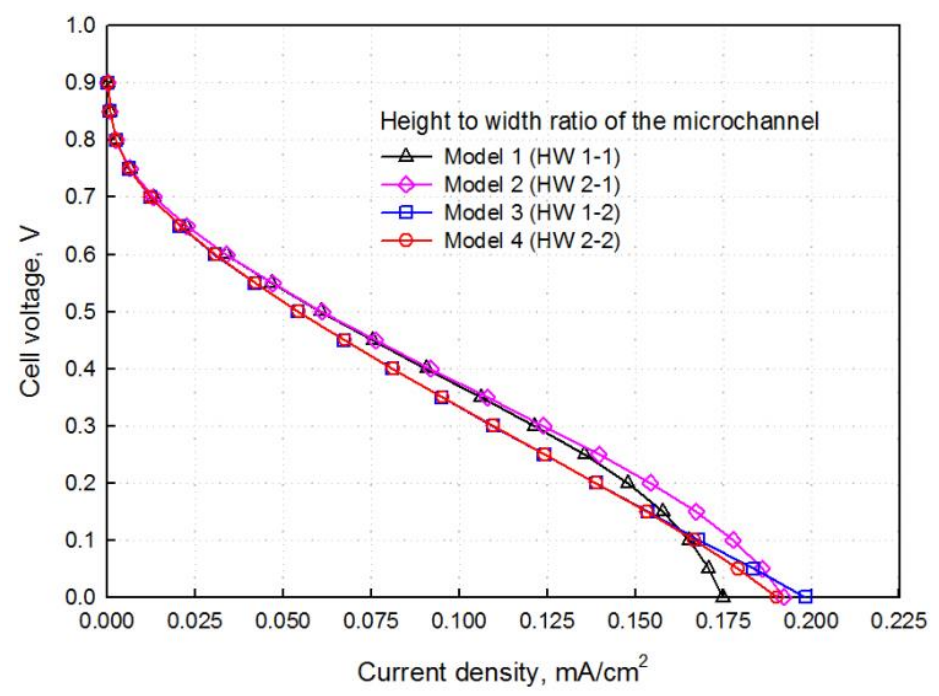

Fig. 3. Polarization curve for four different from Height to Width ratio of the flow channel: HW 1:1, 2:1, 1:2, and 2:2 with $0.05-\mathrm{MH}_{2}$ and $0.5 \mathrm{~mL} / \mathrm{min}$

Figure 4 shows the hydrogen and oxygen concentration distribution at the electrode surface at a different position, respectively. Figure 4 demonstrates that both streams flow to the channel exit, and the inter-diffusion area becomes wide. At a flow rate of $0.05 \mathrm{~mL} / \mathrm{min}$, such phenomenon diffusion at HW 2:1 (model 2) is more important than at a higher rate of flow. Figure 4 shows a higher oxygen distribution as the liquid torrent flows through the cathode's trailing edge until the concentration saturates. However, oxygen diffusion in the channel allows oxygen absorption to quickly scatter across the microchannel behind the trailing edge of the electrode.
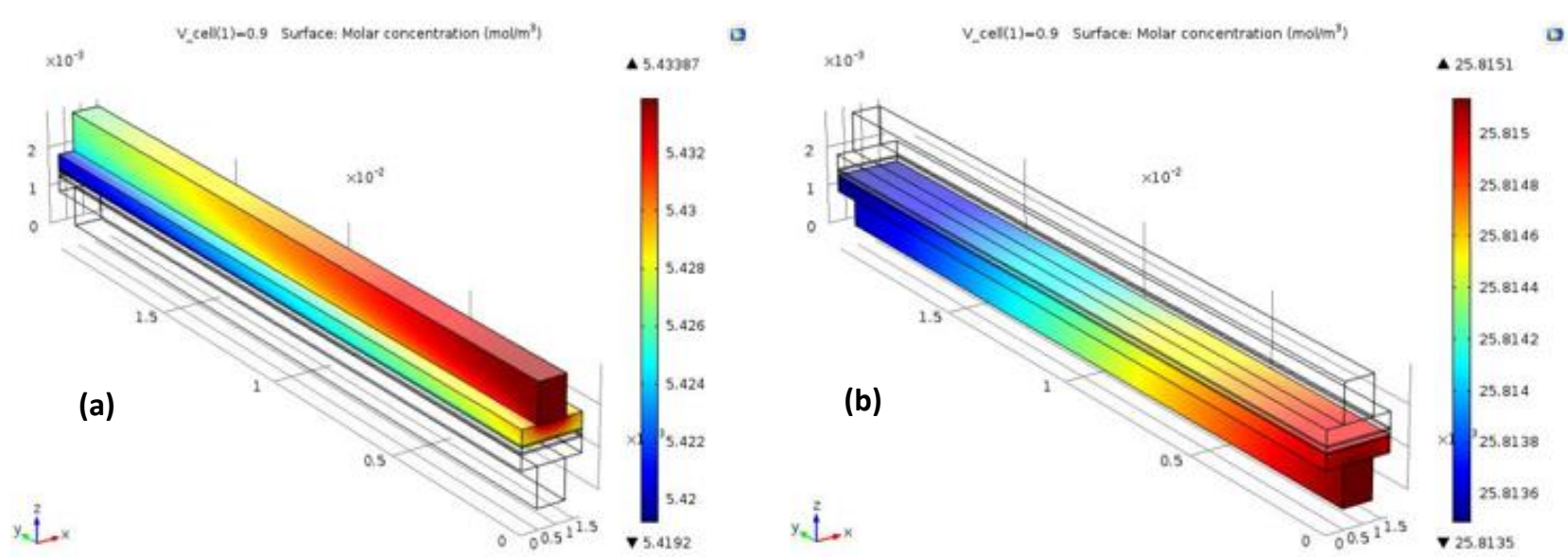

Fig. 4. Performance of the cell: (a) Cathode hydrogen concentration at model-2 (HW 2-1) at 0.05-M with volumetric flow rate $0.5 \mathrm{~mL} / \mathrm{min}$; (b) Anode hydrogen concentration at model-2 (HW 2-1) at 0.05-M with volumetric flow rate $0.5 \mathrm{~mL} / \mathrm{min}$ 
The concentrations of hydrogen and oxygen at the same voltage level is shown in Figure 5(a). It is indicated that significantly the oxygen concentration at the porous electrode and prior to the exit of the flow channel is lower than that at the inlet level. The same trend is found at the anode, with a more uniform hydrogen concentration. Figure $5(b)$ shows the local current density peak around the edge of the electrode close to the middle of the channel with two different anode permeabilities. The acceleration of flow rate increase the visibility of local current density variation on the electrode surface, as given in Figure 5 . The distribution of local current density on the surface of the anode and cathode catalyst layers (in the zx plane) with a voltage of $0.4 \mathrm{~V}$ with a hydrogen inlet. The amount of transported oxygen to the catalyst layer determines the local current density performance.
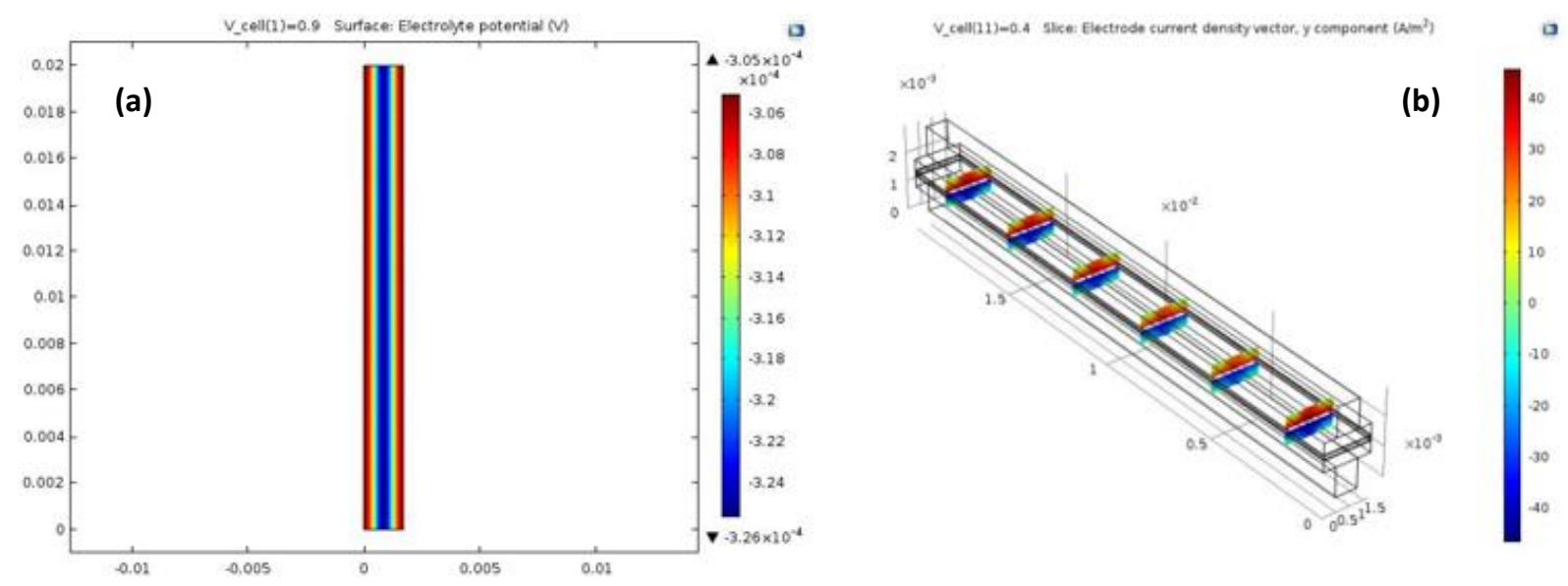

Fig. 5. Performance PEM fuel cell: (a) Membrane current density; (b) Cathode current distribution

The diffusion of oxygen affects the distribution of current density thus appears uniform on the surface of the cathode catalyst. The diffusion limitation causes the local current density on the surface of the cathode catalyst layer to be lower than that of the anode catalyst layer that the reaction on the surface cannot be thoroughly occupied. The distribution of current in the cathode catalyst layer extends the highest current as a function of mass transport resistance, ionic resistance, and charge transfer resistance. It can be seen that the distribution of the highest current in the cell is a function of the highest depletion of the oxygen concentration at the exit side of the duct, and the amount of reacted and carried oxygen towards the electrode surface under the mass transfer conditions. The density of current enlarges with the decline of oxygen concentration in the cathode catalyst layer. It is also shown that the density of local current shifted almost uniformly to the right side of the anode electrode surface.

\section{Conclusions}

The study managed to numerically simulate the mass transport and the polymer electrolyte membrane fuel cells (PEM fuel-cells) distribution under various conditions, equipped either with one stack panel. The PEM fuel cell with a $20 \mathrm{~mm}, 1 \mathrm{~mm}$, and $1 \mathrm{~mm}$ high cell channel was numerically checked at a $0.5 \mathrm{ml} / \mathrm{min}$ volumetric flow rate. The simulation study obtained cell efficiency which is voltage-current density and power current density. The PEM fuel cell current distribution described the ions transfer from anolyte streams in the anode catalyst layer towards the cathode catalyst layer and vice versa. This phenomenon generated a high value of current at the interface of the catholyte streams and the cathode catalyst layer. In difference, the interface of the cathode catalyst and the gas distribution layer generated a minimum current. 
The distribution of the current generated at the electrode surface was lower than that of the distribution of the current generated by the electric generator current at the electrode surface which is closer to the catalytic layer during the electrochemical reaction process in the centre plane. The low density of local currents closes to the inlet moderately surged along the flow channel towards the centre of the channel, then decreases in the area towards the outlet. Higher cell performance near the inlet area is associated with better electrolyte conductivity (lower ohmic overvoltage). The cell performance around the outlet channel was lower due to higher water flooding on the cathode drain side. At the cathode layer with higher moisture content, the mass transport limitation in the gas diffusion layer will be decreased. In contrast, the cathode layer with a lower moisture content has an increased of mass transport limitation in the gas diffusion layer.

\section{Acknowledgment}

The authors gratefully acknowledge the financial support provided by the Ministry of Research Technology and Higher Education of Indonesia under the contract of DIKTI 152/SP2H/AMD/LT/DRPM/2020 and P3M Polines with contract number of 25/E1/KPT/2020.

\section{References}

[1] Herlambang, Yusuf Dewantoro, Jin-Cherng Shyu, and Shun-Ching Lee. "Numerical simulation of the performance of air-breathing direct formic acid microfluidic fuel cells." Micro \& Nano Letters 12, no. 11 (2017): 860-865. https://doi.org/10.1049/mnl.2017.0322

[2] Zhou, Daming, Fei Gao, Ahmed Al-Durra, Elena Breaz, Alexandre Ravey, and Abdellatif Miraoui. "Development of a multiphysical 2-D model of a PEM fuel cell for real-time control." IEEE Transactions on Industry Applications 54, no. 5 (2018): 4864-4874. https://doi.org/10.1109/TIA.2018.2839082

[3] Herlambang, Yusuf Dewantoro, Shun-Ching Lee, and Huan-Chi Hsu. "Numerical estimation of photovoltaicelectrolyzer system performance on the basis of a weather database." International Journal of Green Energy 14, no. 7 (2017): 575-586. https://doi.org/10.1080/15435075.2017.1307200

[4] Khazaee, I., and A. Rava. "Numerical simulation of the performance of solid oxide fuel cell with different flow channel geometries." Energy 119 (2017): 235-244. https://doi.org/10.1016/i.energy.2016.12.074

[5] Thomas, Sobi, Samuel Simon Araya, Steffen Henrik Frensch, Thomas Steenberg, and Søren Knudsen Kær. "Hydrogen mass transport resistance changes in a high temperature polymer membrane fuel cell as a function of current density and acid doping." Electrochimica Acta $317 \quad$ (2019): $521-527$. https://doi.org/10.1016/i.electacta.2019.06.021

[6] Li, Wenkai, Qinglei Zhang, Chao Wang, Xiaohui Yan, Shuiyun Shen, Guofeng Xia, Fengjuan Zhu, and Junliang Zhang. "Experimental and numerical analysis of a three-dimensional flow field for PEMFCs." Applied Energy 195 (2017): 278-288. https://doi.org/10.1016/i.apenergy.2017.03.008

[7] Berning, Torsten, and Ned Djilali. "Three-dimensional computational analysis of transport phenomena in a PEM fuel cell-a parametric study." Journal of Power Sources 124, no. 2 (2003): 440-452. https://doi.org/10.1016/S03787753(03)00816-4

[8] Nguyen, Phong Thanh, Torsten Berning, and Ned Djilali. "Computational model of a PEM fuel cell with serpentine gas flow channels." Journal of Power Sources 130, no. 1-2 (2004): $149-157$. https://doi.org/10.1016/i.jpowsour.2003.12.027

[9] Haji, Shaker. "Analytical modeling of PEM fuel cell i-V curve." Renewable Energy 36, no. 2 (2011): $451-458$. https://doi.org/10.1016/i.renene.2010.07.007

[10] Eikani, M. H., A. Eliassi, N. Khandan, and V. R. Nafisi. "Design and fabrication of a 300W PEM fuel cell test station." Procedia Engineering 42 (2012): 368-375. https://doi.org/10.1016/i.proeng.2012.07.428

[11] Wang, Xiao-Dong, Wei-Mon Yan, Wen-Chung Won, and Duu-Jong Lee. "Effects of operating parameters on transport phenomena and cell performance of PEM fuel cells with conventional and contracted flow field designs." International Journal of Hydrogen Energy 37, no. $20 \quad$ (2012): 15808-15819. https://doi.org/10.1016/j.ijhydene.2012.02.145

[12] Sun, Hong, Chen Xie, Hao Chen, and Saif Almheiri. "A numerical study on the effects of temperature and mass transfer in high temperature PEM fuel cells with ab-PBI membrane." Applied Energy 160 (2015): 937-944. https://doi.org/10.1016/j.apenergy.2015.02.053 
[13] Najafi, Behzad, Alireza Haghighat Mamaghani, Fabio Rinaldi, and Andrea Casalegno. "Fuel partialization and power/heat shifting strategies applied to a $30 \mathrm{kWel}$ high temperature PEM fuel cell based residential micro cogeneration plant." International Journal of Hydrogen Energy 40, no. 41 (2015): 14224-14234. https://doi.org/10.1016/i.ijhydene.2015.08.088

[14] Ham, Sang-Woo, Su-Young Jo, Hye-Won Dong, and Jae-Weon Jeong. "A simplified PEM fuel cell model for building cogeneration applications." Energy and Buildings $107 \quad$ (2015): $213-225$. https://doi.org/10.1016/i.enbuild.2015.08.023

[15] Authayanun, Suthida, Karittha Im-Orb, and Amornchai Arpornwichanop. "A review of the development of high temperature proton exchange membrane fuel cells." Chinese Journal of Catalysis 36, no. 4 (2015): 473-483. https://doi.org/10.1016/S1872-2067(14)60272-2

[16] Devrim, Yılser, Huseyin Devrim, and Inci Eroglu. "Development of 500 W PEM fuel cell stack for portable power generators." International Journal of Hydrogen Energy 40, no. 24 (2015): 7707-7719. https://doi.org/10.1016/i.ijhydene.2015.02.005

[17] Herlambang, Yusuf Dewantoro, Jin-Cherng Shyu, and Shun-Ching Lee. "Numerical simulation of the performance of air-breathing direct formic acid microfluidic fuel cells." Micro \& Nano Letters 12, no. 11 (2017): 860-865. https://doi.org/10.1049/mnl.2017.0322

[18] Rezazadeh, Sajad, Haleh Sadeghi, Reza Mirzaei, and Iraj Mirzaei. "Numerical Investigation of Flow Channel Geometrical Configuration Design Effect on a Proton Exchange Membrane Fuel Cell Performance and Mass Transport Phenomenon." In 2018 2nd International Conference on Smart Grid and Smart Cities (ICSGSC), pp. 137141. IEEE, 2018. https://doi.org/10.1109/ICSGSC.2018.8541298

[19] Deng, Suxiang, Mohammad K. Hassan, Kenneth A. Mauritz, and Jimmy W. Mays. "Hydrocarbon-based fuel cell membranes: Sulfonated crosslinked poly (1, 3-cyclohexadiene) membranes for high temperature polymer electrolyte fuel cells." Polymer 73 (2015): 17-24. https://doi.org/10.1016/i.polymer.2015.07.030

[20] Yang, W. J., H. Y. Wang, and Y. B. Kim. "Channel geometry optimization using a 2D fuel cell model and its verification for a polymer electrolyte membrane fuel cell." International Journal of Hydrogen Energy 39, no. 17 (2014): 9430 9439. https://doi.org/10.1016/i.ijhydene.2014.03.243

[21] Rostami, Leila, Puriya Mohamad Gholy Nejad, and Ali Vatani. "A numerical investigation of serpentine flow channel with different bend sizes in polymer electrolyte membrane fuel cells." Energy 97 (2016): 400-410. https://doi.org/10.1016/i.energy.2015.10.132

[22] Rosli, R. E., A. B. Sulong, W. R. W. Daud, M. A. Zulkifley, T. Husaini, M. I. Rosli, E. H. Majlan, and M. A. Haque. "A review of high-temperature proton exchange membrane fuel cell (HT-PEMFC) system." International Journal of Hydrogen Energy 42, no. 14 (2017): 9293-9314. https://doi.org/10.1016/j.ijhydene.2016.06.211

[23] Rasheed, Raj Kamal Abdul, Quan Liao, Zhang Caizhi, and Siew Hwa Chan. "A review on modelling of high temperature proton exchange membrane fuel cells (HT-PEMFCs)." International Journal of Hydrogen Energy 42, no. 5 (2017): 3142-3165. https://doi.org/10.1016/j.ijhydene.2016.10.078

[24] Dekel, Dario R. "Review of cell performance in anion exchange membrane fuel cells." Journal of Power Sources 375 (2018): 158-169. https://doi.org/10.1016/i.jpowsour.2017.07.117

[25] Herlambang, Yusuf Dewantoro, Anis Roihatin, Kurnianingsih, Totok Prasetyo, Shun-Ching Lee, and Jin-Cherng Shyu. "Computation and numerical modeling of fuel concentration distribution and current density on performance of the microfluidic fuel cell." In AIP Conference Proceedings, vol. 2197, no. 1, p. 090001. AIP Publishing LLC, 2020. https://doi.org/10.1063/1.5140949

[26] Nikiforow, K., P. Koski, and J. Ihonen. "Discrete ejector control solution design, characterization, and verification in a 5 kW PEMFC system." International Journal of Hydrogen Energy 42, no. 26 (2017): 16760-16772. https://doi.org/10.1016/i.ijhydene.2017.05.151

[27] Li, Wenkai, Qinglei Zhang, Chao Wang, Xiaohui Yan, Shuiyun Shen, Guofeng Xia, Fengjuan Zhu, and Junliang Zhang. "Experimental and numerical analysis of a three-dimensional flow field for PEMFCs." Applied Energy 195 (2017): 278-288. https://doi.org/10.1016/i.apenergy.2017.03.008

[28] Aman, Nurul Ashikin Mohd Nazrul, Andanastuti Muchtar, Mahendra Rao Somalu, Masli Irwan Rosli, and Noor Shieela Kalib. "Overview of Computational Fluid Dynamics Modelling in Solid Oxide Fuel Cell." Journal of Advanced Research in Fluid Mechanics and Thermal Sciences 52, no. 2 (2018): 174-181.

[29] Norman, Nur Wardah, Mahendra Rao Somalu, and Andanastuti Muchtar. "A short review on the proton conducting electrolytes for solid oxide fuel cell applications." Journal of Advanced Research in Fluid Mechanics and Thermal Sciences 52, no. 2 (2018): 115-122.

[30] Herlambang, Yusuf Dewantoro, Anis Roihatin, Shun-Ching Lee, and Jin-Cherng Shyu. "MEMS-Based Microfluidic Fuel Cell for In Situ Analysis of the Cell Performance on The Electrode Surface." In Journal of Physics: Conference Series, vol. 1444, no. 1, p. 012044. IOP Publishing, 2020. https://doi.org/10.1088/1742-6596/1444/1/012044 